\title{
Nanostructured Semiconducting Metal Oxide Gas Sensors for Acetaldehyde Detection
}

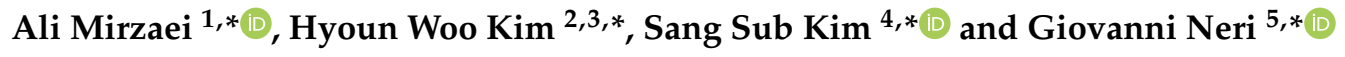 \\ 1 Department of Materials Science and Engineering, Shiraz University of Technology, Shiraz 71557-13876, Iran \\ 2 The Research Institute of Industrial Science, Hanyang University, Seoul 04763, Korea \\ 3 Division of Materials Science and Engineering, Hanyang University, Seoul 04763, Korea \\ 4 Department of Materials Science and Engineering, Inha University, Incheon 22212, Korea \\ 5 Department of Engineering, University of Messina, 98166 Messina, Italy \\ * Correspondence: mirzaei@sutech.ac.ir (A.M.); hyounwoo@hanyang.ac.kr (H.W.K.); sangsub@inha.ac.kr \\ (S.S.K.); gneri@unime.it (G.N.)
}

Received: 26 August 2019; Accepted: 8 November 2019; Published: 13 November 2019

check for updates

\begin{abstract}
Volatile organic compounds (VOCs) are among the most abundant air pollutants. Their high concentrations can adversely affect the human body, and therefore, early detection of VOCs is of outmost importance. Among the different VOCs, in this review paper we have focused our attention to the monitoring of acetaldehyde by chemiresistive gas sensors fabricated from nanostructured semiconducting metal oxides. These sensors can not only provide a high sensing signal for detection of acetaldehyde but also high thermal and mechanical stability along with a low price. This review paper is divided into three major sections. First, we will introduce acetaldehyde as an important VOC and the importance of its detection. Then, the fundamentals of chemiresistive gas sensors will be briefly presented, and in the last section, a survey of the literature on acetaldehyde gas sensors will be presented. The working mechanism of acetaldehyde sensors, their structures, and configurations are reviewed. Finally, the future development outlook and potential applications are discussed, giving a complete panoramic view for researchers working and interested in acetaldehyde detection for different purposes in many fundamental and applicative fields.
\end{abstract}

Keywords: acetaldehyde; chemiresistive gas sensor; nanostructured metal oxide; sensing mechanism

\section{Introduction}

By definition, volatile organic compounds (VOCs) are organic compounds with a low boiling point, $\left(50-100{ }^{\circ} \mathrm{C}\right.$ to $\left.240-260{ }^{\circ} \mathrm{C}\right)$ and with saturation vapor pressures higher than $102 \mathrm{kPa}$ at $25{ }^{\circ} \mathrm{C}$ [1]. They are air pollutants and mostly are emitted from industrial factories and vehicles. They accelerate the formation of secondary organic aerosols, and under oxidized conditions, they will convert them to particles [2]. Accordingly, they cause different environmental problems and also have detrimental effects on human health [3].

Aldehydes are a class of VOCs that are highly reactive and odorous. They are one of the most common sources of pollution in air because they are not only used in many chemical adhesives such as cigarette adhesives [4] but also are produced in many industrial processes or incomplete combustions [5]. In particular, they can be formed as a product of incomplete wood combustion in fireplaces and woodstoves, pulp and paper factories, internal combustion engines and turbines, and vehicle exhaust fumes [6]. Formaldehyde $(\mathrm{HCHO})$ and acetaldehyde $\left(\mathrm{CH}_{3} \mathrm{CHO}\right)$ are considered two of the most important aldehydes $[7,8]$. They are known as carcinogenic and probably carcinogenic agents, respectively $[9,10]$. 
Acetaldehyde, with the systematic name of ethanal [11], is a small molecule comprising of only four hydrogen atoms, two carbon atoms and one oxygen atom with a low molecular weight $(44.05 \mathrm{~g} / \mathrm{mol})$ [12], as shown in Figure 1. It has an aroma like oranges, low boiling point $\left(20.2^{\circ} \mathrm{C}\right)$, and high solubility in water and lipids [13]. The indoor sources of acetaldehyde include laminates, building materials, wood ceilings, wooden varnished, etc., while its outdoor sources include power plants, wood, trash, oil and gas extraction, cement kilns, refineries, and automobile exhausts [14]. It is also the most abundant carcinogen of tobacco smoke [15]. Acetaldehyde is widely employed to produce acetic acid, acetate esters, pentaerythritol, and pyridine bases [16]. In addition, it is used in the dairy industry as a synthetic flavoring component and food additive [17].

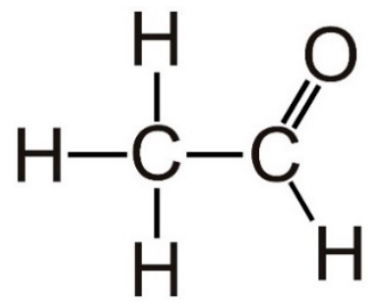

Figure 1. Structure of acetaldehyde.

Acetaldehyde is also a highly toxic compound [18]. The effects of acetaldehyde on the human body include eye irritation, headache, vomiting, liver diseases, and detrimental effects on the throat, skin, and the respiratory tract [19-21]. In particular, because of the pungent odor of acetaldehyde, it is extremely irritating at concentrations above $50 \mathrm{ppm}$ [14]. In addition, it can be a cause of sick building syndrome, so-called SBS, even at ppb levels [22,23]. Acetaldehyde has a strong electrophilic nature and can damage DNA in humans, and it is considered as a possible human carcinogen [24,25]. Furthermore, it can easily react with Vitamin B1, leading to B1 deficiency. Accordingly, it can cause mental illness, visual disturbances, and poor memory in human beings. To avoid such problems, $100 \mathrm{ppm}$ as a permissible exposure limit of acetaldehyde has been proposed [26].

Acetaldehyde is present in both indoor and outdoor environment and its detection is therefore very important for monitoring environmental and domestic pollution. For monitoring acetaldehyde, conventional analytical techniques, such as gas chromatography, are widely used but they are bulky, time consuming and expensive. Accordingly, compact, robust, and inexpensive solid-state gas sensors are required. Among the others, conductometric solid-state gas sensors represent an effective alternative. Although semiconducting oxide-based chemoresistors are characterized by high-sensitivity, often the low selectivity limits their practical use. Then, due to scientific and practical importance, a survey of literature on acetaldehyde chemoresistive gas sensors will be presented and discussed.

\section{Chemiresistive Gas Sensors}

Nowadays, gas sensors are widely utilized in different areas including public safety, industrial processes, domestic safety, underground mining, and monitoring of environmental pollution and air quality in vehicles [27]. So far, different types of gas sensors such as surface acoustic wave [28], optical [29], gasochromic [30], thermoelectric [31], electrochemical [32]. and chemiresistive [33-35] gas sensors for detection of VOCs have been introduced. Among them, chemiresistive gas sensors are very popular owing to their high sensitivity, short response time, high stability, reproducibility, simple fabrication and operation, and low cost [36-38]. Chemiresistive gas sensors, in which the resistance of the sensing layer changes upon exposure to the target gas, were introduced for the first time about sixty years ago [39]. Depending on the increase or decrease of the resistance and the magnitude of the resistance change, the gas type and its concentration can be estimated $[40,41]$. In chemiresistive gas sensors, surface area, morphology, chemical composition, and sensing temperature are the main factors affecting the gas response [42,43]. 
A typical resistive-based gas sensor consists of a sensitive layer that is deposited on the surface of interdigitated electrodes (Figure 2) printed on an (a) insulating ceramic, (b) plastic, or (c) Si substrate [44]. A heater can also be used on the back of the substrate to raise the sensor temperature up to desired sensing temperatures. However, in some cases, the sensor will be put in a gas chamber in a tubular furnace, where the temperature can be precisely controlled [45].

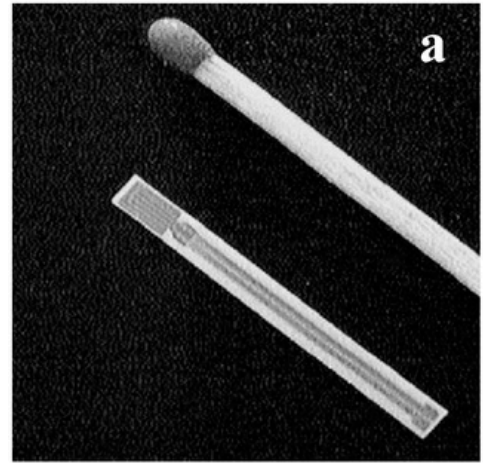

Planar-type gas sensor

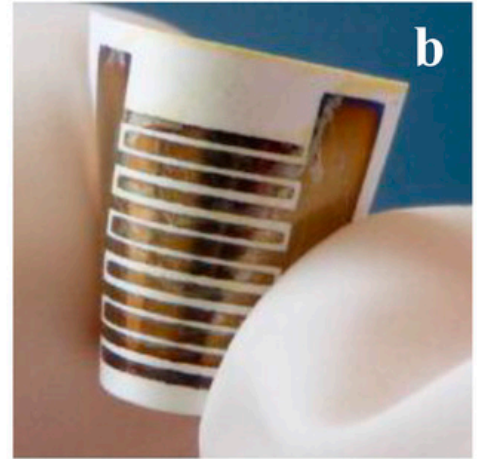

Flexible gas sensor

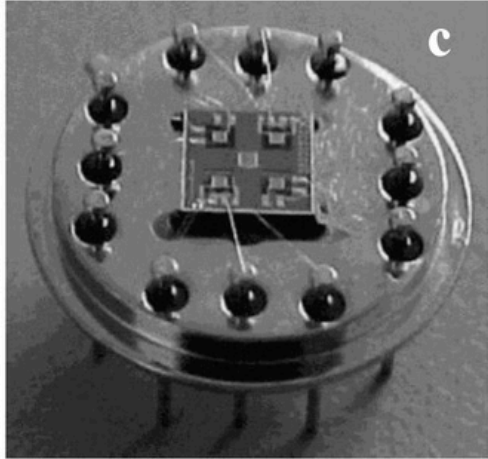

Micromachined gas sensor

Figure 2. Chemoresistive gas sensors with different configurations, (a) Planar-type gas sensor (b) Flexible gas sensor (c) Micromachined gas sensor. Reprinted with permission from [39].

\subsection{General Sensing Mechanism}

Figure 3 schematically shows the acetaldehyde sensing mechanism in both pristine n- or p-type metal oxide chemiresistive sensors. For n-types such as $\mathrm{ZnO}, \mathrm{SnO}_{2}$, initially in air, due to abstraction of the electrons by oxygen species, a so-called electron depletion layer will be created on the surface. Because of this, the resistance in the electron depletion layer is higher than that of the core-region parts of the sensing material (Figure 3a,b). Upon exposure to acetaldehyde gas, it reacts with already adsorbed oxygen ions and the released electrons come back to the surface of the gas sensor. As a result, the resistance of the gas sensor increases, leading to the appearance of a sensing signal. For p-type metal oxides, such as $\mathrm{CuO}$ and $\mathrm{Cr}_{2} \mathrm{O}_{3}$ [46], initially in air, due to extraction of the electrons by oxygen species, a hole accumulation layer will appear on the surface of the gas sensor (Figure 3c,d). Since in p-type metal oxides the main charge carriers are the holes, the resistance in the hole accumulation layer is lower than the core part. In acetaldehyde atmosphere, the released electrons come back to the surface of the gas sensor, leading to higher resistance of the gas sensor and appearance of a sensing signal. A widely used strategy to enhance the gas sensitivity and selectivity is noble metal decoration. The promising effects of noble metals on acetaldehyde detection, which are known as electronic sensitization and chemical sensitization, respectively $[47,48]$, are schematically shown in Figure 3e,f. In electronic sensitization, due to the difference between the work functions of noble metals and metal oxides, often electrons from the sensing layer will be moved to the noble metals to equate the Fermi levels. Therefore, in contact areas between the noble metal and metal oxide, the width of the electron depletion layer increases, leading to greater resistance modulation upon exposure to the acetaldehyde gas. In addition, noble metals can act as catalysts for the decomposition of oxygen molecules and target gases. Therefore, initially the gas will be adsorbed on the surface of noble metals, then it will be decomposed into smaller molecules or atoms, and finally. in a so-called spillover effect, it will be moved to the surface of the neighboring sensing layer. Thus, the noble metals can enhance the sensitivity and selectivity of the gas sensors. 


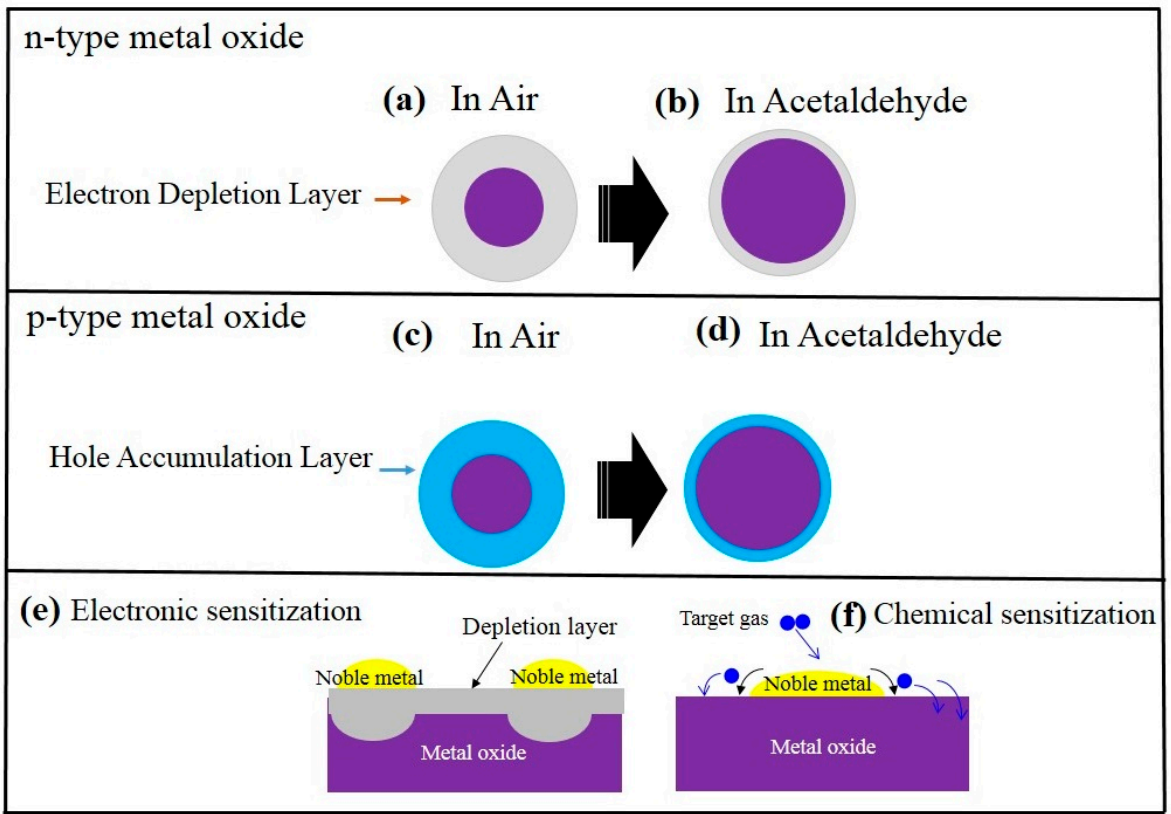

Figure 3. Schematic of acetaldehyde-sensing mechanism in (a,b) n-type metal oxide and (c,d) p-type metal oxide. Effect of noble metals on the gas sensing enhancement: (e) electronic sensitization (f) chemical sensitization.

\section{Acetaldehyde Detection Using Chemiresistive-Based Gas Sensors}

Traditional strategies to determine the concentration of acetaldehyde are the use of gas chromatography, chemiluminescence, cataluminescence, etc. [49]. Even though such techniques are highly sensitive and accurate, they have some disadvantages for online monitoring, need expert operators, and are bulky as well as expensive. Therefore, sensitive, selective, stable, fast, portable, and simply operated sensors are greatly needed for acetaldehyde detection [6,50]. For practical applications, an acetaldehyde gas sensor should have following merits: (i) high sensitivity; (ii) high selectivity; (iii) fast dynamics; (iv) long-term stability; (v) reproducibility; (vi) low power consumption; and (vi) low cost. Even though metal-oxide-based gas sensors have most of the above merits, their selectivity and power consumption is a challenge and more research is needed to realize a high acetaldehyde gas sensor for practical applications. In the remaining parts of this review paper, we will discuss chemiresistive acetaldehyde gas sensors on the basis of the metal oxides.

\subsection{Morphology-Engineered Nanostructures as Acetaldehyde Gas Sensors}

It is well-known that morphology engineering is one of the best strategies to improve the sensing capabilities of metal oxide gas sensors [51,52]. For example, regarding zinc oxide ( $\mathrm{ZnO})$, which is one of the most used sensing materials [37,53,54], different morphologies of $\mathrm{ZnO}$ such as nanoparticles (NPs), tetrapods, nanobeads, and nanotubes have been used for gas-sensing studies (Figure 4).
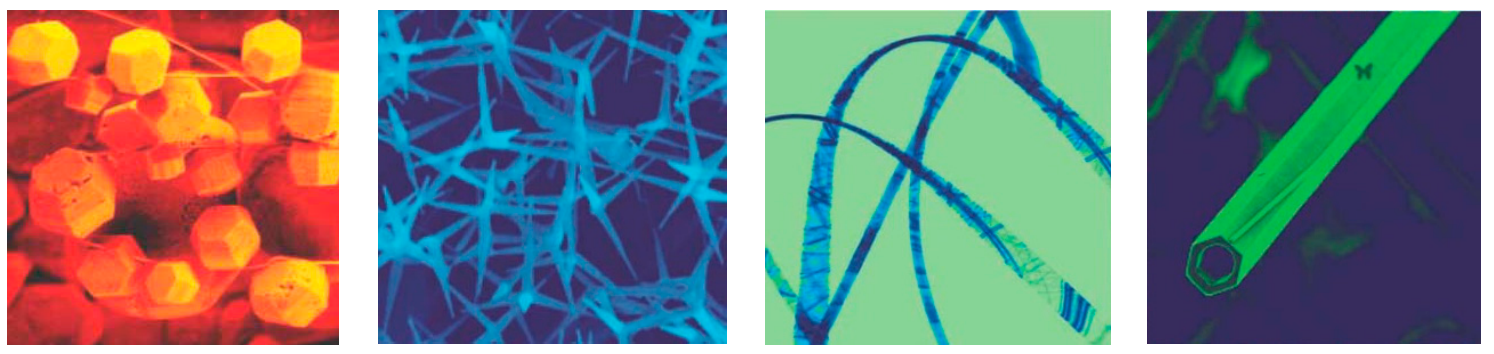

Figure 4. Example of some typical $\mathrm{ZnO}$ morphologies used in the fabrication of gas sensing devices. From right to left: nanoparticles, tetrapods, nanobeads, and nanotubes. Adapted from [51]. 
In Table 1, we present some ZnO-based sensors with different morphologies reported for the sensing of acetaldehyde in the literature (Table 1). As can be seen, ZnO-based sensors with different morphologies are able to detect low and high concentrations of acetaldehyde gas at different sensing temperatures.

Table 1. Acetaldehyde sensing properties of some $\mathrm{ZnO}$-based gas sensors reported in the literature.

\begin{tabular}{ccccc}
\hline Morphology & $\begin{array}{c}\text { Concentration } \\
(\mathbf{p p m})\end{array}$ & $\begin{array}{c}\text { Operating } \\
\text { Temperature }\left({ }^{\circ} \mathbf{C}\right)\end{array}$ & Response $\left(\mathbf{R}_{\mathbf{a}} / \mathbf{R}_{\mathbf{g}}\right)$ & Ref. \\
\hline Al-doped ZnO & 10 & 500 & 2250 & {$[55]$} \\
ZnO powders & 2 & 450 & 5.73 & {$[14]$} \\
$\mathrm{ZnO}-\mathrm{NiCo}_{2} \mathrm{O}_{4}$ nanofibers & 100 & 250 & $\sim 3$ & {$[56]$} \\
0.15 mol\% Au-ZnO NPs & 100 & 377 & $\sim 7$ & {$[57]$} \\
$\mathrm{ZnO}$ particles & 250 & 400 & 45 & {$[58]$} \\
ZnO tetrapods & 50 & 25 & 47.5 & {$[5]$} \\
ZnO nanoaggregates & 200 & 220 & 77 & {$[59]$} \\
ZnO sheets & 1 & 400 & 5.30 & {$[60]$} \\
ZnO rods & 250 & & 8 & {$[62]$} \\
ZnO flowers & 100 & 25 & 14 & 2.85 \\
ZnO petals & 10 & & 800 & {$[26]$} \\
ZnO branched nanorods & 10 & &
\end{tabular}

For example, $\mathrm{ZnO}$ tetrapods with nanosized dimensions were synthesized with a vapor phase method for aldehyde detection [5]. The employed method was catalyst-free and offered very high yield (a few grams were easily produced). On average, the diameter of tetrapods was $60 \mathrm{~nm}$, and their length was $1 \mathrm{~mm}$. The dynamic gas responses were obtained at different temperatures, showing that response/recovery times decreased when the temperature increased. At $400{ }^{\circ} \mathrm{C}$, the sensor revealed a higher response to propionaldehyde $\left(\mathrm{CH}_{3} \mathrm{CH}_{2} \mathrm{CHO}\right)$ compared to acetaldehyde due to the higher number of electrons returning back to the $\mathrm{ZnO}$ when the molecule was completely oxidized [5]:

$$
\begin{gathered}
\mathrm{CH}_{3} \mathrm{CHO}+5 \mathrm{O}^{-} \rightarrow 2 \mathrm{CO}_{2}+2 \mathrm{H}_{2} \mathrm{O}+5 \mathrm{e}, \\
\mathrm{CH}_{3} \mathrm{CH}_{2} \mathrm{CHO}+8 \mathrm{O}^{-} \rightarrow 3 \mathrm{CO}_{2}+3 \mathrm{H}_{2} \mathrm{O}+8 \mathrm{e} .
\end{gathered}
$$

As shown in the above equations, the reaction of acetaldehyde and propionaldehyde with adsorbed electrons releases five and eight electrons, respectively. Accordingly, the response to acetaldehyde was slightly lower than the response to propionaldehyde. Interestingly, it was found that at $\mathrm{T}>350{ }^{\circ} \mathrm{C}$, the response was independent of the relative humidity $(\mathrm{RH})$ value $(0-75 \%)$.

In another study, flower-like $\mathrm{ZnO}$ nanostructures comprised of $\mathrm{ZnO}$ nanorods were fabricated through a hydrothermal synthesis method [62]. The hydrothermal method is a cost-effective and versatile method with the possibility of morphology control and is widely used for synthesis of metal oxides for sensing applications [63]. The high response the gas sensor to acetaldehyde compared to $\mathrm{CO}$ gas was related to the electron-donating effect of acetaldehyde (10 electrons), which was greater than that of the $\mathrm{CO}$ gas (two electrons).

$\mathrm{ZnO}$ nanosheets with two-dimensional morphology have attracted a lot of attention for sensing studies due to their high surface areas. In this regard, a fast acetaldehyde gas sensor was introduced using nanosheet-like $\mathrm{ZnO}$ nanostructures synthesized through a sonochemical method followed by subsequent etching [64]. The $\mathrm{ZnO}$ nanosheets had a high surface area, resulting in an enhanced sensing performance down to the ppb level. At the optimal sensing temperature of $220^{\circ} \mathrm{C}$, the sensor was able to detect even $50 \mathrm{ppb}$ of acetaldehyde gas. Furthermore, the sensor revealed a linear response to acetaldehyde along with fast response and recovery times. The response and recovery times of the sensor to acetaldehyde were 8 and $60 \mathrm{~s}$, respectively, which is very fast for practical applications. In fact, the presence of abundant channels and open space between the $\mathrm{ZnO}$ nanosheets accelerated the gas diffusion and decreased the response and recovery times. 


\subsubsection{Nanoparticle-Based Acetaldehyde Gas Sensors}

Metal oxide NPs can be easily synthesized through different chemical synthesis methods. Accordingly, there is much literature regarding use of metal oxide NPs as gas sensors. For example, a ZnO NP-based gas sensor working at $450{ }^{\circ} \mathrm{C}$ revealed a response $\left(\mathrm{R}_{\mathrm{a}} / \mathrm{R}_{\mathrm{g}}\right)$ of 5.73 to only $2 \mathrm{ppm}$ acetaldehyde. The high response of the gas sensor was attributed to the complete oxidation of acetaldehyde catalyzed by the surface, where through a reaction with adsorbed oxygen, acetaldehyde transformed into acetic acid [14]:

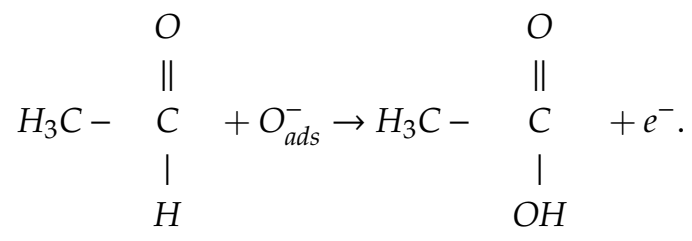

In the humid condition, a decrease in the sensor response resulted due to the competition between water vapor and acetaldehyde. As a result, the number of available sites for acetaldehyde adsorption decreased. In addition, the increase in RH led to a decrease in the adsorbed oxygen species, and accordingly, the conductivity was increased in humid air. Therefore, the baseline resistance decreased to a lower resistance for higher RH values [65].

In another study, Rai and Yu synthesized ZnO NPs by a citrate-assisted hydrothermal method for gas sensor studies [58]. The maximum response $\left(\mathrm{R}_{\mathrm{a}} / \mathrm{R}_{\mathrm{g}}\right)$ of the fabricated sensor was 45.75 at $400{ }^{\circ} \mathrm{C}$ for $250 \mathrm{ppm}$ of acetaldehyde gas. However, the selectivity of the sensor was not so good because it also revealed a high response to ethanol due to the electron-donating effect of ethanol, which was similar to acetaldehyde. In the case of ethanol, both dehydration and dehydrogenation reactions are possible as follows [58]:

$$
\begin{array}{cl}
\mathrm{C}_{2} \mathrm{H}_{5} \mathrm{OH} \rightarrow \mathrm{C}_{2} \mathrm{H}_{4}+\mathrm{H}_{2} \mathrm{O} & \text { (dehydration reaction, acidic oxide), } \\
2 \mathrm{C}_{2} \mathrm{H}_{5} \mathrm{OH} \rightarrow 2 \mathrm{CH}_{3} \mathrm{CHO}+2 \mathrm{H}_{2} \quad \text { (dehydrogenation reaction, basic oxide). }
\end{array}
$$

Ethylene $\left(\mathrm{C}_{2} \mathrm{H}_{4}\right)$ or acetaldehyde $\left(\mathrm{CH}_{3} \mathrm{CHO}\right)$ intermediates are subsequently oxidized to $\mathrm{CO}, \mathrm{CO}_{2}$, and $\mathrm{H}_{2} \mathrm{O}$ as follows [58]:

$$
\begin{gathered}
\mathrm{C}_{2} \mathrm{H}_{4}+3 \mathrm{O}_{2}{ }^{2-} \text { (ads) } \rightarrow 2 \mathrm{CO}_{2}+2 \mathrm{H}_{2} \mathrm{O}+6 \mathrm{e} . \\
2 \mathrm{CH}_{3} \mathrm{CHO} \text { (ads) }+5 \mathrm{O}_{2}{ }^{2-} \text { (ads) } \rightarrow 4 \mathrm{CO}_{2}+4 \mathrm{H}_{2} \mathrm{O}+10 \mathrm{e}^{-} .
\end{gathered}
$$

Since the $\mathrm{ZnO}$ has a basic nature, the dehydrogenation reaction is preferred on the surface of $\mathrm{ZnO}$, and the number of released electrons is comparable with that of acetaldehyde. Consequently, the higher response of acetaldehyde relative to ethanol was related to the long chain of reaction for ethanol gas, which had a slow kinetic nature [58].

Another fast dynamics sensor was realized using randomly interconnected ZnO NPs that were prepared using a simple chemical spray pyrolysis method [54]. The sensor revealed a response $\left(R_{a} / R_{g}\right)$ of 50 to $50 \mathrm{ppm}$ acetaldehyde gas with the response and recovery times of only 60 and $40 \mathrm{~s}$, respectively. Furthermore, the sensor showed a high selectivity to acetaldehyde relative to the interfering gases. This was related to the low bond dissociation energy for acetaldehyde ( $364 \mathrm{~kJ} \mathrm{~mol}^{-1}$ ), which was smaller than that of other gases, resulting in a good gas selectivity. Even though the bond dissociation energy of formaldehyde was comparable to that of acetaldehyde, a lower response to formaldehyde was obtained. This was related to the electron-donating effects, where the number of electrons released during the reduction of acetaldehyde was more than that of formaldehyde [65].

In an interesting study, cotton fabrics were also used as gas sensors. Untreated and $\mathrm{ZnO}$ $\mathrm{NP}$-added cotton fabrics were used to sense $100 \mathrm{ppm}$ of acetaldehyde and other interfering gases at $25{ }^{\circ} \mathrm{C}$ [66]. An improved acetaldehyde response was obtained for $\mathrm{ZnO}$-modified cotton fabric 
owing to the homogeneous distribution of $\mathrm{ZnO}$ NPs and the presence of high porosities between the inter-yarn pores.

Apart from $\mathrm{ZnO}$, many other metal oxides can be used as sensing layers in chemiresistive sensors. For example, ultrafine $\mathrm{CuO}$ NPs were fabricated via a facile chemical route for acetaldehyde sensing studies [67]. At an optimal temperature of $200{ }^{\circ} \mathrm{C}$, the sensor showed a response $\left(\Delta R / R_{a}\right)$ of 29.23 towards $100 \mathrm{ppm}$. The acetaldehyde-sensing mechanism of the p-type $\mathrm{CuO}$ sensor is shown in Figure 5 . As presented in Figure 5a, initially in air, a hole accumulation layer was formed on the surface of $\mathrm{CuO}$ NPs due to the adsorption of oxygen ions. When the sensor was exposed to acetaldehyde (Figure 5b), acetaldehyde molecules reacted with oxygen ions and released electrons back to the $\mathrm{CuO}$ surface. Accordingly, the width of the hole accumulation layer decreased, and the resistance of the gas sensor increased. However, the sensor showed a reduced response in humid air because of the occupation of adsorption sites by water molecules.

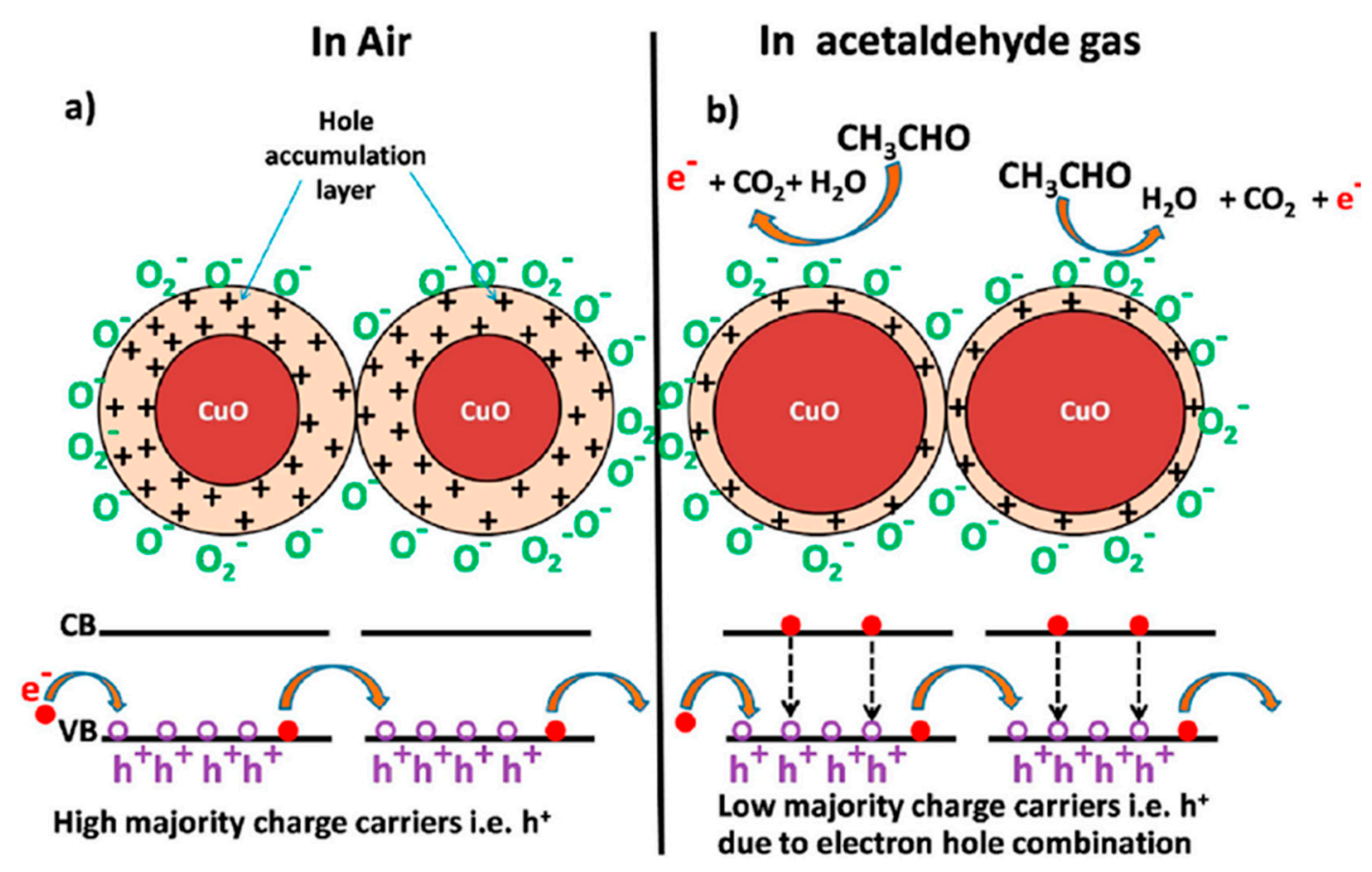

Figure 5. Schematics of acetaldehyde-sensing mechanism of $\mathrm{CuO}$ nanoparticles (NPs) (a) in air (b) in acetaldehyde atmosphere. (CB is conduction band and VB is valence band). Reprinted with permission from [67].

In another study, $\operatorname{In}_{2} \mathrm{O}_{3}$ NPs were synthesized through a one-step microwave hydrothermal route [68]. The NPs showed a response $\left(\mathrm{R}_{\mathrm{a}} / \mathrm{R}_{\mathrm{g}}\right)$ of 11.06 to $100 \mathrm{ppm}$ acetaldehyde at $300{ }^{\circ} \mathrm{C}$. The sensing mechanism is shown in Figure 6. Initially, in air, due to the adsorption of oxygen species, an electron depleted layer was formed. When the $\operatorname{In}_{2} \mathrm{O}_{3}$ sensor was put in acetaldehyde atmosphere, the acetaldehyde vapor molecules reacted with the adsorbed oxygen ions on the surface of $\mathrm{In}_{2} \mathrm{O}_{3} \mathrm{NPs}$, and the released electrons caused a significant change in the sensor resistance, contributing to the sensor response [68].

$\mathrm{Mn}_{2} \mathrm{O}_{3}$ is rarely reported for sensing studies. However, a very fast acetaldehyde gas sensor based on $\alpha-\mathrm{Mn}_{2} \mathrm{O}_{3} \mathrm{NP}$ thin film that was deposited on silica substrates with a spray pyrolysis technique, was reported [69]. The sensing tests showed that the sensing response was higher to acetaldehyde than any other vapors. The high sensing response to acetaldehyde at room temperature was related to the high electron-donating ability of acetaldehyde as well as the catalytic effect of $\alpha-\mathrm{Mn}_{2} \mathrm{O}_{3}$ towards oxygen. Furthermore, the sensor showed fast dynamics, and for 5 to $75 \mathrm{ppm}$ acetaldehyde, it displayed a short response $(9 \mathrm{~s})$ and recovery $(\sim 35 \mathrm{~s})$ time, which is greatly needed for practical applications. 


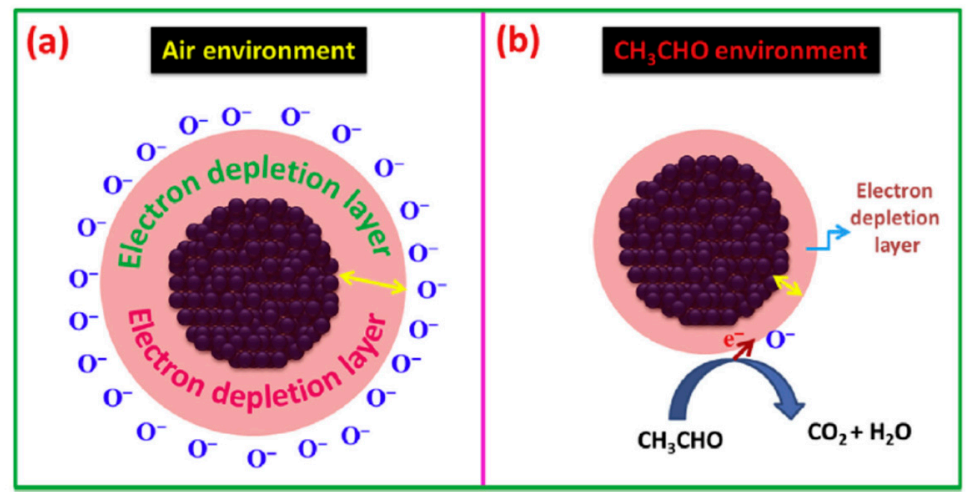

Figure 6. Schematic of the acetaldehyde sensing mechanism for an $\operatorname{In}_{2} \mathrm{O}_{3}$ gas sensor in (a) air and (b) acetaldehyde atmosphere. Reprinted with permission from [68].

Table 2 lists some acetaldehyde gas sensors based on metal oxides. As can be seen, different metal oxides in pristine or composite forms can be used for the realization of acetaldehyde gas sensors. However, in general, their performance is lower those of the sensors based on $\mathrm{ZnO}$.

Table 2. Comparison of the performance of different metal oxides toward acetaldehyde.

\begin{tabular}{ccccc}
\hline Sensing Material & Gas Conc. $(\mathbf{p p m})$ & $\mathbf{T}\left({ }^{\circ} \mathbf{C}\right)$ & Response $\left(\mathbf{R}_{\mathbf{a}} / \mathbf{R}_{\mathbf{g}}\right)$ & Ref. \\
\hline $1 \mathrm{wt} \% \mathrm{Ru} / 10 \mathrm{wt} \%$ & 100 & 200 & 11 & {$[65]$} \\
$\mathrm{WO}_{3} / \mathrm{SnO}_{2}$ & 100 & 200 & $23.29\left(\Delta \mathrm{R} / \mathrm{R}_{\mathrm{a}}\right)$ & {$[67]$} \\
$\mathrm{CuO} \mathrm{NPs}$ & 1000 & 100 & 5 & {$[70]$} \\
$0.1 \mathrm{wt} \%$ graphene- $\mathrm{WO}_{3}$ & 100 & 300 & 11.06 & {$[68]$} \\
$\mathrm{In}_{2} \mathrm{O}_{3}$ nanospheres & 50 & 250 & 4 & {$[71]$} \\
$\mathrm{NiO}_{\text {nanotetrahedra }}$ & 500 & 300 & 0.85 & {$[72]$} \\
$\mathrm{Au} @ \mathrm{SnO}_{2}$ core-shell NPs & & & \\
\hline
\end{tabular}

\subsubsection{Effect of UV Light}

The sensing layer can absorb UV light and further dissociates the gaseous compounds. UV light may increase the density of free electron-hole pairs. Moreover, depending on the UV intensity and UV morphology of the sensing layer, the response of gas sensors can be successfully enhanced [73]. Therefore, UV light can be used to decrease the power consumption of the gas sensors [74]. Unfortunately, in the literature, there are not many reports on the effect of UV light on acetaldehyede sensing. In this regard, a ZnO NP (50-70 nm)-based gas sensor was realized and used for acetaldehyde detection under UV-light irradiation [56]. The sensor under UV light was able to detect $50 \mathrm{ppb}$ acetaldehyde gas. Since acetaldehyde at even low concentrations is considered a carcinogenic agent, the developed sensor could be used for practical application of acetaldehyde detection with low power consumption [75].

\subsubsection{Noble Metal Loading}

Promising effects of noble metals on the gas response of metal-oxide-based gas sensors were already discussed in Section 2.1. Despite this, there are few studies related to the decoration of noble metals for realization of highly sensitive acetaldehyde gas sensors. As an example, effects of metal decoration on the acetaldehyde response of ZnO NPs were also studied. ZnO NP (30-40 nm) metals were fabricated by using a chemical precipitation method and subsequently were loaded with $\mathrm{Rh}$, $\mathrm{Mg}, \mathrm{Y}, \mathrm{Pd}, \mathrm{V}$, or La by an impregnation method [76]. Among the different noble metal loaded gas sensors, the response of the $\mathrm{Ru}-\mathrm{ZnO}$ sensor was higher to alcohol and acetaldehyde than to the other gases. It was also found that the greater the response to acetaldehyde, the higher the response to alcohol. Therefore, it was concluded that the presence of acetaldehyde favored the response to alcohol. 
To gain further insight, the catalytic oxidation of alcohol over ZnO NPs was studied in a reactor, and the reaction products were studied by gas chromatography. It was revealed that the response of the $\mathrm{ZnO}$ sensor to ethanol was dependent on the conversion of ethanol to intermediate products, and acetaldehyde, which was one of the intermediate products, increased the response to alcohol [76].

In another study using noble metal decoration, the acetaldehyde gas-sensing performance of pristine and noble metal (Pt and $\mathrm{Rh}$ )-loaded $\mathrm{SnO}_{2} \mathrm{NPs}$ were investigated by Shimizu and his collaborators [77]. The highest response to acetaldehyde was for the $\mathrm{SnO}_{2}$ loaded with $0.1 \mathrm{wt} \% \mathrm{Rh}$ at $350{ }^{\circ} \mathrm{C}$. In the case of pristine $\mathrm{SnO}_{2}$ operating at $500{ }^{\circ} \mathrm{C}$, and also for $3.0 \mathrm{Pt} / \mathrm{SnO}_{2}$ operating at $450{ }^{\circ} \mathrm{C}$, some amount of acetaldehyde was consumed during its diffusion through pores in the sensor into the interior region; therefore, the steady-state acetaldehyde concentration in the interior was lower than that in the ambient atmosphere. However, in the case of $0.1 \mathrm{Rh} / \mathrm{SnO}_{2}$ at $350{ }^{\circ} \mathrm{C}$, partial consumption of acetaldehyde during diffusion into the interior was small, and most of the acetaldehyde and its derivatives were oxidized almost completely only in the interior region. The temperature gradient associated with the heater location facilitated such a difference in oxidation behavior between the surface and the interior region of the sensor [77].

\subsubsection{Composites}

Heterojunction formation is another strategy for realization of high performance gas sensors. In this context, PdO-ZnO core-shell nanosheets (NS) heterojunctions were synthesized for the realization of high-performance acetaldehyde gas sensors. The size of the Pd NPs was $10 \pm 5 \mathrm{~nm}$, and these were encapsulated in the center of the $\mathrm{ZnO}$ shell of $40-50 \mathrm{~nm}$. The fabricated sensor revealed the highest response $\left(\mathrm{R}_{\mathrm{a}} / \mathrm{R}_{\mathrm{g}}\right)$ of 76 to $100 \mathrm{ppm}$ acetaldehyde at $350{ }^{\circ} \mathrm{C}$, which was much higher than that of pristine $\mathrm{ZnO} N S$ sensors $\left(\mathrm{R}_{\mathrm{a}} / \mathrm{R}_{\mathrm{g}}=18\right)$. Since the work function of $\mathrm{PdO}(7.9 \mathrm{eV})$ was higher than the work function of $\mathrm{ZnO}(5.3 \mathrm{eV})$, the $\mathrm{PdO} / \mathrm{ZnO} \mathrm{p}-\mathrm{n}$ heterojunction formed a wide depletion layer and thus energy band bending at the interface of the $\mathrm{PdO}$ and $\mathrm{ZnO}$. Therefore, the resistance of the sensor increased. However, upon injection of acetaldehyde gas, the resistance significantly decreased. Moreover, because the PdO NPs act as a catalyst, they facilitated the dissociation of oxygen molecules into $\mathrm{O}$ atoms and enhanced the reactions between the oxygen ions and acetaldehyde molecules. Furthermore, the $\mathrm{PdO}-\mathrm{ZnO} \mathrm{p}-\mathrm{n}$ heterojunction had a larger surface area in comparison to a pristine sensor, and this led to the availability of much higher adsorption sites on the surface of the heterojunction gas sensor, eventually leading to enhancement of the gas response [78].

Graphene is a well-known two-dimensional material with outstanding electrical conductivity [79] that can improve the conductivity of composites, which is beneficial for realization of the gas sensors. However, in pristine form it is rarely used for sensing studies, and it is often used in nanocomposites for this purpose. In this regards, graphene $(0,0.1,0.5,1$ and $3 \mathrm{wt} \%)-\mathrm{WO}_{3}$ nanocomposites were synthesized by a hydrothermal method for acetaldehyde sensing [70]. This revealed that the sensor based on a $0.1 \mathrm{wt} \%$ graphene $-\mathrm{WO}_{3}$ nanocomposite indicated the highest gas response $\left(\mathrm{R}_{\mathrm{a}} / \mathrm{R}_{\mathrm{g}}\right)$ of 5 to $1000 \mathrm{ppm}$ acetaldehyde gas along with good selectivity at $100^{\circ} \mathrm{C}$. In the interfaces between graphene and $\mathrm{WO}_{3}$, Schottcky contacts were created, and the graphene- $\mathrm{WO}_{3}$ interface was a forward-biased Schottcky barrier, leading to the easy capture and migration of electrons from $\mathrm{WO}_{3} \mathrm{NP}$ to graphene. In addition, graphene, offered a high surface area for gas adsorption. Thus, the gas-sensing performance of the nanocomposite was improved in the presence of graphene.

Polyaniline (PANI) $)_{x} \mathrm{MoO}_{3}$ and poly(o-anisidine) (PoANIS) ${ }_{x} \mathrm{MoO}_{3}$ composite thin films were synthesized by Itoh and collaborators for acetaldehyde monitoring [23]. These materials were prepared by a modified intercalation method in which a $\left[\mathrm{Na}\left(\mathrm{H}_{2} \mathrm{O}\right)_{2}\right]_{x} \mathrm{MoO}_{3}$ thin film was soaked in two different intercalation solutions, namely PANI or PoANIS solutions. The intercalation solutions were filtrated to remove insoluble polymers that had a degree of polymerization. The hybrid-based sensors prepared by the modified method could detect low concentrations of acetaldehyde gas up to a several tens ppb level, whereas those prepared by the conventional method were not able to sense such low concentrations of 
acetaldehyde due to the presence of insoluble PANI moieties adsorbed onto the surface of the hybrid thin films, which negatively affected the response of the gas sensor.

In an interesting study, $\mathrm{SnO}_{2} \mathrm{NPs}$ mixed with various amounts of $\mathrm{WO}_{3}$ and doped with $\mathrm{Pt}, \mathrm{Ru}$, $\mathrm{Pd}, \mathrm{Ag}, \mathrm{Au}$, and In were also investigated for acetaldehyde-sensing studies [65]. It was found that the $1 \mathrm{wt} \% \mathrm{Ru} / 10 \mathrm{wt} \% \mathrm{WO}_{3} / \mathrm{SnO}_{2}$ gas sensor showed a response of 11 to $100 \mathrm{ppm}$ acetaldehyde at $200{ }^{\circ} \mathrm{C}$. The enhanced gas response can be related to the formation of $\mathrm{WO}_{3} / \mathrm{SnO}_{2}$ heterojunctions and promising effects of Ru.

\subsubsection{Doped Nanostructure as Acetaldehyde Gas Sensors}

Since acetaldehyde is a VOC and there are some other VOCs with almost the same formula, it is very difficult to gain high selectivity to acetaldehyde in metal-oxide-based gas sensors; however, some strategies such as optimization of the sensing temperature, noble metal decoration, doping, use of heterojunctions and use of membranes can enhance the selectivity to acetaldehyde. However, more studies are needed to completely solve the selectivity issue in metal-oxide-based gas sensors. In this regard, Al-doped ZnO NPs were produced through a hydrothermal method for gas sensing application [55]. It was reported that the acetaldehyde-sensing response $\left(\mathrm{R}_{\mathrm{a}} / \mathrm{R}_{\mathrm{g}}=2250\right)$ to $10 \mathrm{ppm}$ acetaldehyde at $500^{\circ} \mathrm{C}$ was $\sim 173$ and 125 times higher than those of $\mathrm{C}_{7} \mathrm{H}_{8}$ and $\mathrm{C}_{6} \mathrm{H}_{6}$ vapors, respectively. Selectivity pattern of the sensor to different interfering gases demonstrated the excellent selectivity of the gas sensor to acetaldehyde (Figure 7). This was related to the larger dipole moment in the molecular structure of acetaldehyde $(2.7 \mathrm{D})$ than that in $\mathrm{NO}(0.16 \mathrm{D}), \mathrm{NO}_{2}(0.32 \mathrm{D}), \mathrm{TMA}(0.61 \mathrm{D})$, benzene $(0 \mathrm{D}), \mathrm{NH}_{3}(1.47 \mathrm{D})$, toluene $(0.31 \mathrm{D})$, and $\mathrm{CO}(0.122 \mathrm{D})$. In fact, the dipole moment of a gas molecule affects the attractive Van der Waals force between the gas molecule and sensing layer. Thus, due to having a higher dipole moment, the number of molecules of acetaldehyde that were adsorbed on the surface of the gas sensor was more than that of other gases [55].

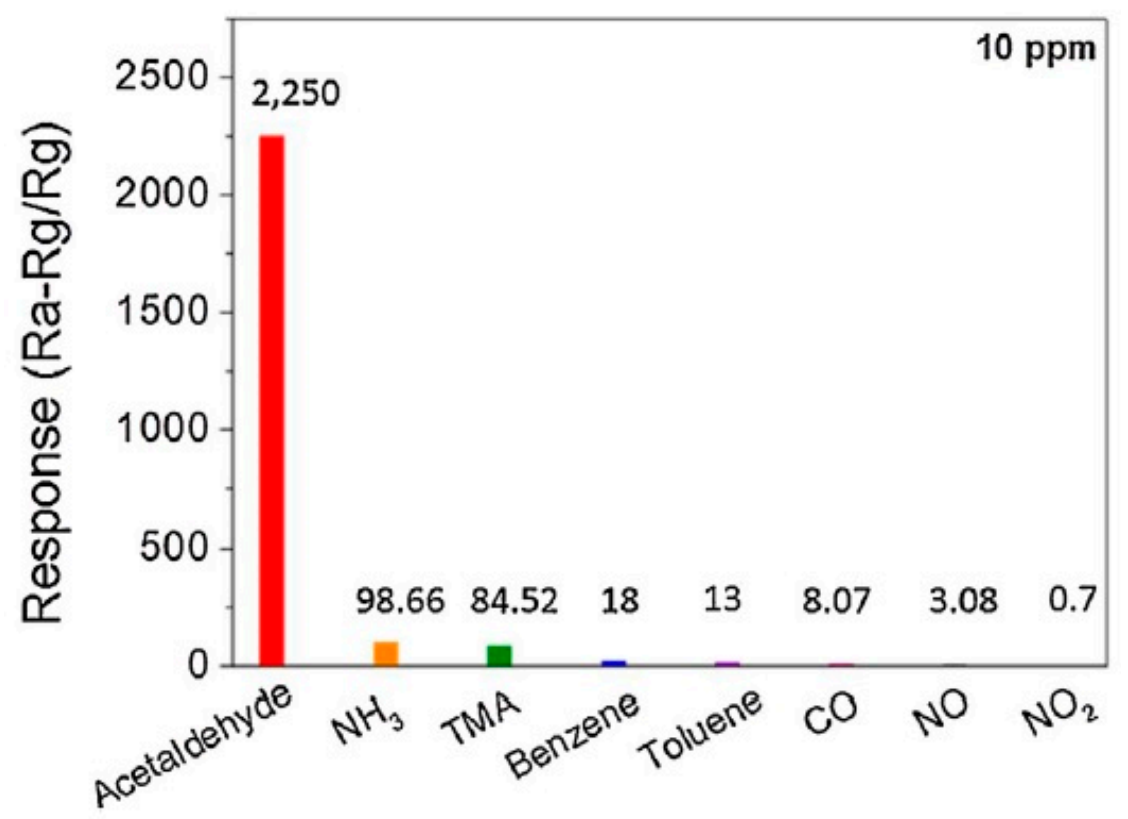

Figure 7. Selectivity pattern of the Al-doped $\mathrm{ZnO}$ gas sensor to different gases. Reprinted with permission from [55].

When Al-doped ZnO NPs were in air (Figure 8a), oxygen ions were adsorbed on the surface of the gas sensor, resulting in the formation of a thick depletion layer on the surface of ZnO NPs. In acetaldehyde atmosphere (Figure 8b), an electron exchange occurred due to the interaction of acetaldehyde and the adsorbed oxygen species, resulting in the oxidation of acetaldehyde and the release of electrons into the sensor surface. Thus, the electrical resistance decreased and a sensing 
signal was resulted. The response of the Al-doped ZnO NPs was 16 times higher than that of pristine $\mathrm{ZnO}$ NPs to acetaldehyde. The reasons for the high response of the Al-doped sensor were reported as follows: Firstly, the amount of oxygen vacancies that acted as adsorption sites for acetaldehyde on the surface of the $\mathrm{ZnO}$ NPs in the lattice of $\mathrm{ZnO}$ was found to increase after $\mathrm{Al}$ doping (Figure 8c). Secondly, due to the presence of additional carriers in Al-doped ZnO NPs and the shift of the Fermi level, the band gas was larger than that of pristine ZnO NPs. An increase in carrier concentration led to an increase in ionized oxygen species on the surface of $\mathrm{ZnO}$, which reacted with acetaldehyde. Thirdly, the surface area of the Al-doped $\mathrm{ZnO} N P s\left(\sim 42 \mathrm{~m}^{2} / \mathrm{g}\right)$ was larger than that of the pristine $\mathrm{ZnO}$ NPs $\left(\sim 35 \mathrm{~m}^{2} / \mathrm{g}\right)$. Accordingly, many more acetaldehyde molecules were adsorbed on the surface of the Al-doped sensor, resulting in a higher gas response in the Al-doped $\mathrm{ZnO}$ gas sensor [55].

(a)

In Air

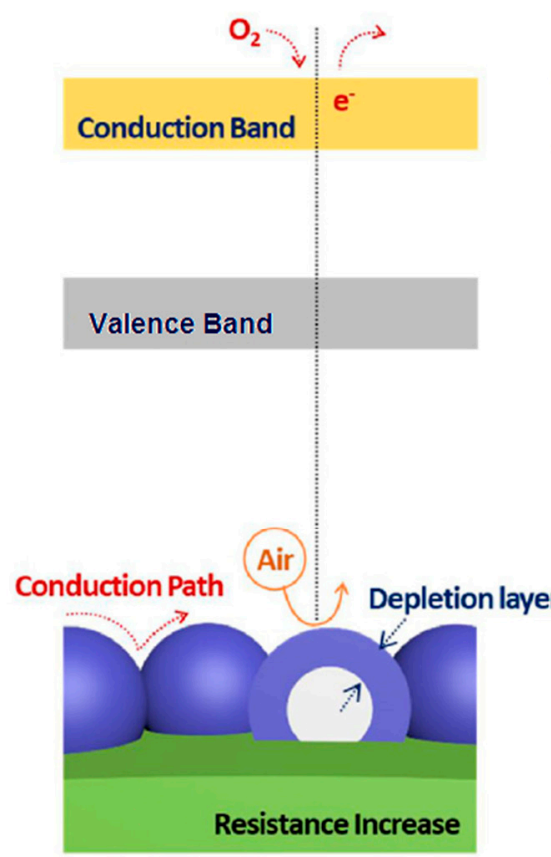

(b)

In Acetaldehyde: un-doped ZnO

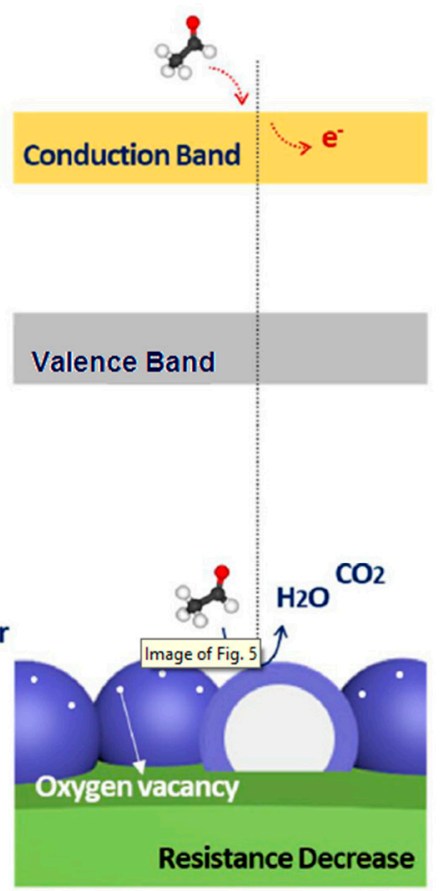

(c)

In Acetaldehyde: Al-doped ZnO

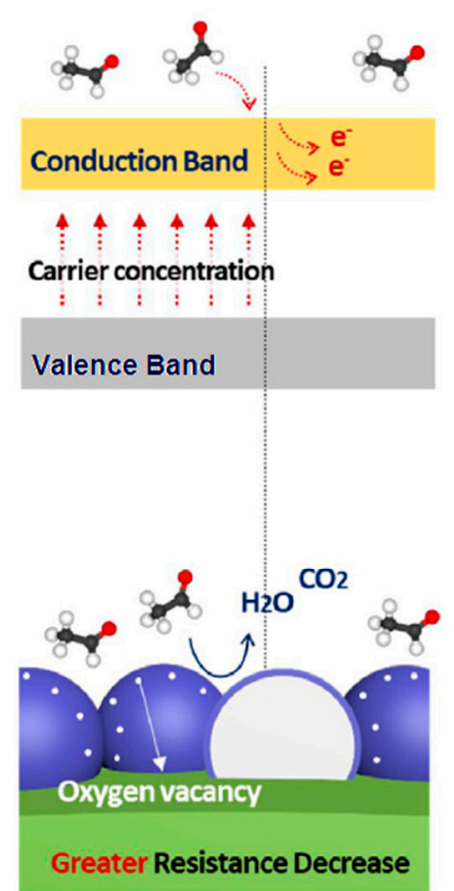

Figure 8. The sensing mechanism in (a) pristine or Al-doped ZnO NPs in air, (b) pristine ZnO NPs, and (c) Al-doped ZnO NPs in acetaldehyde atmosphere. Reprinted with permission from [55].

Transition metal dopants such as $\mathrm{Cr}, \mathrm{Co}, \mathrm{Ni}$, and $\mathrm{Cu}$ have good potential for oxygen adsorption as well as good catalytic activity to different VOCs [80-82]. In an interesting study, pristine and Co-, $\mathrm{Ni}$-, and $\mathrm{Cu}$-doped $\mathrm{ZnO}$ nanostructures were realized by a chemical spray pyrolysis method [26]. The sensing response to $10 \mathrm{ppm}$ acetaldehyde was 2.85, 800, 2.59, and 21.36 for the pristine and Co-, $\mathrm{Ni}$-, and $\mathrm{Cu}$-doped $\mathrm{ZnO}$-based gas sensors, respectively. The high response to acetaldehyde was due to the lower bond dissociation energy of acetaldehyde $\left(364 \mathrm{~kJ}^{\mathrm{mol}}{ }^{-1}\right)$ than other gases and vapors such as ammonia $\left(435 \mathrm{kJmol}^{-1}\right)$, ethanol $\left(436 \mathrm{kJmol}^{-1}\right)$, methanol $\left(436.8 \mathrm{kJmol}^{-1}\right)$, formaldehyde $\left(364 \mathrm{kJmol}^{-1}\right)$, and toluene $\left(368 \mathrm{~kJ} \cdot \mathrm{mol}^{-1}\right)$. The low response of the Ni-doped sensor was due to the morphology of this sensor, which was different from other sensors and had a much lower surface area. On the other hand, the Co-doped sensor showed the highest response to acetaldehyde due to its high catalytic activity to this gas and high surface area. In addition, the initial resistance of the pristine, $\mathrm{Ni}$, and $\mathrm{Cu}$-doped $\mathrm{ZnO}$ sensors were lower than the Co-doped $\mathrm{ZnO}$ gas sensor. Since a higher number of electrons was presented on the surface of the Co-doped $\mathrm{ZnO}$ sensor than the other sensors, the change in the width of the electron-depletion layer during the exposure to acetaldehyde was higher than the other sensors [26]. 
Not only are metals used as dopants in $\mathrm{ZnO}$ nanostructures, but non-metallic elements have also been used for this purpose. Fluorine is a highly electronegative element, and it can significantly reduce the resistance of the sensing layer. In this context, fluorine-doped $\mathrm{ZnO}$ film was produced using a chemical spray pyrolysis technique [83]. At room temperature, it revealed a response $\left(R_{a} / R_{g}\right)$ of 4.8 to $100 \mathrm{ppm}$ acetaldehyde gas. In addition, the response increased by increasing of the fluorine dopant due to a decrease in the grain size. With an increase in fluorine dopant, grain size was decreased and the higher surface area along with porous nature of the sensing layer led to an enhanced response to acetaldehyde.

\section{Conclusions and Outlooks}

In this review paper, chemiresitive-based gas sensors for the detection of acetaldehyde were reported and their functioning mechanism and performances were discussed. From the literature, different metal oxides were used for this purpose. Among them, $\mathrm{ZnO}$ is the most widely used for acetaldehyde gas sensing. The fundamentals of these sensors have been highlighted, but although there are some reports on acetaldehyde gas adsorption on transition metal oxides, the acetaldehyde-sensing mechanism in chemiresistive sensors has not been completely explained until now. Indeed, research needs to uncover the details of the change of the electronic properties of the sensing layer following the adsorption of acetaldehyde to enhance the sensor performance for this gas. Regarding practical applications, there are some challenges for the realization of highly reliable and sensitive sensors for commercial purposes. Important parameters, such as sensitivity, selectivity, stability, as well as reproducibility, should be addressed by different strategies. Compared to traditional analytical techniques, these sensors have greater sensitivity, lower cost, and improved portability. Another advantage is that no pretreatment is necessary, providing savings in the cost and time of analysis. These devices show further straightforward integration with integrated circuit devices. Microfabricated devices indeed offer reduced power consumption and increased portability, thus they are also promising for mobile applications.

Therefore, combining fundamental research on new sensing materials with technological advancement towards sensor miniaturization promises to address some of the challenges to wide-scale deployment of chemiresistive sensors for real-time monitoring of acetaldehyde in many applications.

Author Contributions: Conceptualization, G.N., Original Draft Preparation, A.M., G.N., Writing一Review \& Editing, G.N., A.M., H.W.K., and S.S.K.

Funding: This research received no external funding and the APC was 100\% discounted.

Acknowledgments: This research was supported by the Basic Science Research Program through the National Research Foundation of Korea (NRF) funded by the Ministry of Education (2016R1A6A1A03013422). It was also supported by a National Research Foundation of Korea (NRF) grant funded by the Korean government (MSIT) (2019R1A2C1006193).

Conflicts of Interest: The authors declare no conflict of interest.

\section{References}

1. Qi, Y.; Shen, L.; Zhang, J.; Yao, J.; Lu, R.; Miyakoshi, T. Species and release characteristics of VOCs in furniture coating process. Environ. Pollut. 2019, 245, 810-819. [CrossRef]

2. Hou, H.; Liu, H.; Gao, F.; Shang, M.; Wang, L.; Xu, L.; Yang, W. Packaging $\mathrm{BiVO}_{4}$ nanoparticles in ZnO microbelts for efficient photoelectrochemical hydrogen production. Electrochim. Acta 2018, 283, 497-508. [CrossRef]

3. Katsumata, K.I.; Motoyoshi, R.; Matsushita, N.; Okada, K. Preparation of graphitic carbon nitride $\left(\mathrm{g}-\mathrm{C}_{3} \mathrm{~N}_{4}\right) / \mathrm{WO}_{3}$ composites and enhanced visible-light-driven photodegradation of acetaldehyde gas. J. Hazard. Mater. 2013, 260, 475-482. [CrossRef] [PubMed]

4. He, C.; Jiang, L.-M.; Dai, Y.-H.; Wu, M.-J.; Chen, X.-M.; Cai, C.-Q. Determination of formaldehyde and acetaldehyde in cigarette adhesives by high performance liquid chromatography. Chin. J. Anal. Lab. 2010, 5, 69-72. 
5. Calestani, D.; Mosca, R.; Zanichelli, M.; Villani, M.; Zappettini, A. Aldehyde detection by ZnO tetrapod-based gas sensors. J. Mater. Chem. 2011, 21, 15532-15536. [CrossRef]

6. Cao, X.; Zhang, Z.; Zhang, X. A novel gaseous acetaldehyde sensor utilizing cataluminescence on nanosized $\mathrm{BaCO}_{3}$. Sens. Actuators B Chem. 2004, 99, 30-35. [CrossRef]

7. Delikhoon, M.; Fazlzadeh, M.; Sorooshian, A.; Baghani, A.N.; Golaki, M.; Ashournejad, Q.; Barkhordari, A. Characteristics and health effects of formaldehyde and acetaldehyde in an urban area in Iran. Environ. Pollut. 2018, 242, 938-951. [CrossRef]

8. Santana, F.O.; Campos, V.P.; Cruz, L.P.; Luz, S.R. Formaldehyde and acetaldehyde in the atmosphere of Salvador-Ba, Brazil, using passive sampling. Microchem. J. 2017, 134, 78-86. [CrossRef]

9. Stefanov, B.I.; Topalian, Z.; Granqvist, C.G.; Österlund, L. Acetaldehyde adsorption and condensation on anatase $\mathrm{TiO}_{2}$ : Influence of acetaldehyde dimerization. J. Mol. Catal. A Chem. 2014, 381, 77-88. [CrossRef]

10. Kovács, I.; Farkas, A.P.; Szitás, Á.; Kónya, Z.; Kiss, J. Adsorption, polymerization and decomposition of acetaldehyde on clean and carbon-covered Rh (111) surfaces. Surf. Sci. 2017, 664, 129-136. [CrossRef]

11. Lachenmeier, D.W.; Salaspuro, M. ALDH2-deficiency as genetic epidemiologic and biochemical model for the carcinogenicity of acetaldehyde. Reg. Tox. Pharm. 2017, 86, 128-136. [CrossRef] [PubMed]

12. Raktim Pal Kim, K.-H.; Hong, Y.-J.; Jeon, E.-C. The pollution status of atmospheric carbonyls in a highly industrialized area. J. Hazard. Mater. 2008, 153, 1122-1135.

13. Salaspuro, M. Key role of local acetaldehyde in upper GI tract carcinogenesis. Best Pract. Res. Clin. Gastroenterol. 2017, 31, 491-499. [CrossRef]

14. Giberti, A.; Carotta, M.C.; Fabbri, B.; Gherardi, S.; Guidi, V.; Malagù, C. High-sensitivity detection of acetaldehyde. Sens. Actuators B Chem. 2012, 174, 402-405. [CrossRef]

15. Haussmann, H.J. Use of hazard indices for a theoretical evaluation of cigarette smoke composition. Chem. Res. Toxicol. 2012, 25, 794-810. [CrossRef]

16. Sad, M.E.; Peña, L.G.; Padró, C.L.; Apesteguía, C.R. Selective synthesis of acetaldehyde from lactic acid on acid zeolites. Catal. Today 2018, 302, 203-209. [CrossRef]

17. Balagurunathan, B.; Tan, L.; Zhao, H. Metabolic engineering of Escherichia coli for acetaldehyde overproduction using pyruvate decarboxylase from Zymomonas mobilis. Enzym. Microb. Technol. 2018, 109, 58-65. [CrossRef] [PubMed]

18. Turner, C.; Španěl, P.; Smith, D. A longitudinal study of ethanol and acetaldehyde in the exhaled breath of healthy volunteers using selected-ion flow-tube mass spectrometry. Rapid Commun. Mass Spectrom. 2006, 20, 61-68. [CrossRef] [PubMed]

19. Kanjanasiranont, N.; Prueksasit, T.; Morknoy, D. Inhalation exposure and health risk levels to BTEX and carbonyl compounds of traffic policeman working in the inner city of Bangkok, Thailand. Atmos. Environ. 2017, 152, 111-120. [CrossRef]

20. Zhang, X.; Ye, L.; Li, Y.; Zhang, Y.; Cao, C.; Yang, J.; Qi, F. Acetaldehyde oxidation at low and intermediate temperatures: An experimental and kinetic modeling investigation. Combust. Flame 2018, 191, 431-441. [CrossRef]

21. Smith, D.; Wang, T.; Sulé-Suso, J.; Španěl, P.; Haj, A.E. Quantification of acetaldehyde released by lung cancer cells in vitro using selected ion flow tube mass spectrometry. Rapid Commun. Mass Spectrom. 2003, 17, 845-850. [CrossRef] [PubMed]

22. Tryba, B.; Jafari, S.; Sillanpää, M.; Nitta, A.; Ohtani, B.; Morawski, A.W. Influence of $\mathrm{TiO}_{2}$ structure on its photocatalytic activity towards acetaldehyde decomposition. Appl. Surf. Sci. 2019, 470, 376-385. [CrossRef]

23. Itoh, T.; Matsubara, I.; Shin, W.; Izu, N.; Nishibori, M. Preparation of layered organic-inorganic nanohybrid thin films of molybdenum trioxide with polyaniline derivatives for aldehyde gases sensors of several tens ppb level. Sens. Actuators B Chem. 2008, 128, 512-520. [CrossRef]

24. Zhang, L.; Zhou, M.; Dong, S. A self-powered acetaldehyde sensor based on biofuel cell. Anal. Chem. 2012, 84, 10345-10349. [CrossRef] [PubMed]

25. Verissimo, M.I.; Gamelas, J.A.; Simoes, M.M.; Evtuguin, D.V.; Gomes, M.T.S. Quantifying acetaldehyde in cider using a Mn (III)-substituted polyoxotungstate coated acoustic wave sensor. Sens. Actuators B Chem. 2018, 255, 2608-2613. [CrossRef]

26. Mani, G.K.; Rayappan, J.B.B. ZnO nanoarchitectures: Ultrahigh sensitive room temperature acetaldehyde sensor. Sens. Actuators B.Chem. 2016, 223, 343-351. [CrossRef] 
27. Zhang, J.; Liu, X.; Neri, G.; Pinna, N. Nanostructured materials for room-temperature gas sensors. Adv. Mater. 2016, 28, 795-831. [CrossRef]

28. Gao, F.; Boussaid, F.; Xuan, W.; Tsui, C.Y.; Bermak, A. Dual transduction surface acoustic wave gas sensor for VOC discrimination. IEEE Electron. Device Lett. 2018, 39, 1920-1923. [CrossRef]

29. Zhao, Y.; Zaghloul, M.; Lilach, Y.; Benkstein, K.; Semancik, S. Metal Organic Framework-Coated Optical VOC Gas Sensor. In Proceedings of the 2018 IEEE Photonics Conference (IPC), Reston, VA, USA, 30 September-4 October 2018.

30. Rizzo, G.; Arena, A.; Bonavita, A.; Donato, N.; Neri, G.; Saitta, G. Gasochromic response of nanocrystalline vanadium pentoxide films deposited from ethanol dispersions. Thin Solid Films 2010, 518, 7124-7127. [CrossRef]

31. Rajanna, K. Development of thermoelectric gas sensors for volatile organic compounds. In Proceedings of the SENSORS, 2006 IEEE, Daegu, Korea, 22-25 October 2006; pp. 716-718.

32. Mori, M.; Nishimura, H.; Itagaki, Y.; Sadaoka, Y. Potentiometric VOC detection in air using 8YSZ-based oxygen sensor modified with $\mathrm{SmFeO}_{3}$ catalytic layer. Sens. Actuators B Chem. 2009, 142, 141-146. [CrossRef]

33. Kim, J.H.; Lee, J.H.; Mirzaei, A.; Kim, H.W.; Kim, S.S. $\mathrm{SnO}_{2}$ (n)-NiO (p) composite nanowebs: Gas sensing properties and sensing mechanisms. Sens. Actuators B Chem. 2018, 258, 204-214. [CrossRef]

34. Mirzaei, A.; Park, S.; Sun, G.J.; Kheel, H.; Lee, C.; Lee, S. $\mathrm{Fe}_{2} \mathrm{O}_{3} / \mathrm{Co}_{3} \mathrm{O}_{4}$ composite nanoparticle ethanol sensor. J. Korean Phys. Soc. 2016, 69, 373-380. [CrossRef]

35. Mirzaei, A.; Park, S.; Kheel, H.; Sun, G.J.; Ko, T.; Lee, S.; Lee, C. Acetone Sensors Based on $\operatorname{In}_{2} \mathrm{O}_{3}-\mathrm{Co}_{3} \mathrm{O}_{4}$ Composite Nanoparticles. J. Nanosci. Nanotechnol. 2017, 17, 4087-4090. [CrossRef]

36. Mirzaei, A.; Leonardi, S.G.; Neri, G. Detection of hazardous volatile organic compounds (VOCs) by metal oxide nanostructures-based gas sensors: A review. Ceram. Int. 2016, 42, 15119-15141. [CrossRef]

37. Mirzaei, A.; Neri, G. Microwave-assisted synthesis of metal oxide nanostructures for gas sensing application: A review. Sen. Actuators B Chem. 2016, 237, 749-775. [CrossRef]

38. Mirzaei, A.; Janghorban, K.; Hashemi, B.; Neri, G. Metal-core@ metal oxide-shell nanomaterials for gas-sensing applications: A review. J. Nanoparticle Res. 2015, 17, 371. [CrossRef]

39. Neri, G. First fifty years of chemoresistive gas sensors. Chemosensors 2015, 3, 1-20. [CrossRef]

40. Mirzaei, A.; Kim, J.H.; Kim, H.W.; Kim, S.S. Resistive-based gas sensors for detection of benzene, toluene and xylene (BTX) gases: A review. J. Mater. Chem. C 2018, 6, 4342-4370. [CrossRef]

41. Mirzaei, A.; Kim, S.S.; Kim, H.W. Resistance-based $\mathrm{H}_{2} \mathrm{~S}$ gas sensors using metal oxide nanostructures: A review of recent advances. J. Hazard. Mater. 2018, 357, 314-331. [CrossRef]

42. Leonardi, S. Two-dimensional zinc oxide nanostructures for gas sensor applications. Chemosensors 2017, 5, 17. [CrossRef]

43. Mirzaei, A.; Kim, J.H.; Kim, H.W.; Kim, S.S. How shell thickness can affect the gas sensing properties of nanostructured materials: Survey of literature. Sens. Actuators B Chem. 2018, 258, 270-294. [CrossRef]

44. Mirzaei, A.; Janghorban, K.; Hashemi, B.; Bonyani, M.; Leonardi, S.G.; Neri, G. A novel gas sensor based on $\mathrm{Ag} / \mathrm{Fe}_{2} \mathrm{O}_{3}$ core-shell nanocomposites. Ceram. Int. 2016, 42, 18974-18982. [CrossRef]

45. Kim, J.Y.; Lee, J.H.; Kim, J.H.; Mirzaei, A.; Kim, H.W.; Kim, S.S. Realization of $\mathrm{H}_{2} \mathrm{~S}$ sensing by Pd-functionalized networked CuO nanowires in self-heating mode. Sens. Actuators B Chem. 2019, 299, 126965. [CrossRef]

46. Kim, H.-J.; Lee, J.-H. Highly sensitive and selective gas sensors using p-type oxide semiconductors: Overview. Sens. Actuators B Chem. 2014, 192, 607-627. [CrossRef]

47. Kim, J.H.; Zheng, Y.; Mirzaei, A.; Kim, H.W.; Kim, S.S. Synthesis and selective sensing properties of rGO/metal-coloaded $\mathrm{SnO}_{2}$ nanofibers. J. Electron. Mater. 2017, 46, 3531-3541. [CrossRef]

48. Choi, M.S.; Bang, J.H.; Mirzaei, A.; Oum, W.; Na, H.G.; Jin, C.; Kim, S.S.; Kim, H.W. Promotional effects of $\mathrm{ZnO}$-branching and Au-functionalization on the surface of $\mathrm{SnO} 2$ nanowires for $\mathrm{NO}_{2}$ sensing. J. Alloy. Comp. 2019, 786, 27-39. [CrossRef]

49. Yang, P.; Lau, C.; Liang, J.Y.; Lu, J.Z.; Liu, X. Zeolite-based cataluminescence sensor for the selective detection of acetaldehyde. Lum. J. Biol. Chem. Lum. 2007, 22, 473-479. [CrossRef]

50. Abideen, Z.U.; Kim, J.H.; Lee, J.H.; Kim, J.Y.; Mirzaei, A.; Kim, H.W.; Kim, S.S. Electrospun metal oxide composite nanofibers gas sensors: A review. J. Korean Ceram. Soc. 2017, 54, 366-379. [CrossRef]

51. Wang, Z.L. Nanostructures of zinc oxide. Mater. Today 2004, 7, 26-33. [CrossRef]

52. Ahmad, R.; Majhi, S.M.; Zhang, X.; Swager, T.M.; Salama, K.N. Recent progress and perspectives of gas sensors based on vertically oriented ZnO nanomaterials. Adv. Colloid Interface Sci. 2019, 270, 1-27. [CrossRef] 
53. Kim, J.H.; Mirzaei, A.; Kim, H.W.; Kim, S.S. Low power-consumption CO gas sensors based on Au-functionalized $\mathrm{SnO}_{2}-\mathrm{ZnO}$ core-shell nanowires. Sens. Actuators B Chem. 2018, 267, 597-607. [CrossRef]

54. Gao, R.; Cheng, X.; Gao, S.; Zhang, X.; Xu, Y.; Zhao, H.; Huo, L. Highly selective detection of saturated vapors of abused drugs by ZnO nanorod bundles gas sensor. Appl. Surf. Sci. 2019, 485, 266-273. [CrossRef]

55. Yoo, R.; Li, D.; Rim, H.J.; Cho, S.; Lee, H.S.; Lee, W. High sensitivity in Al-doped ZnO nanoparticles for detection of acetaldehyde. Sens. Actuators B Chem. 2018, 266, 883-888. [CrossRef]

56. Liang, Y.; Liu, W.; Hu, W.; Zhou, Q.; He, K.; Xu, K.; Yang, Y.; Yu, T.; Yuan, C. Synthesis and gas-sensing properties of ZnO@ NiCo2O4 core@ shell nanofibers. Mater. Res. Bull. 2019, 114, 1-9. [CrossRef]

57. Suematsu, K.; Watanabe, K.; Tou, A.; Sun, Y.; Shimanoe, K. Ultraselective toluene-gas sensor: Nanosized gold loaded on zinc oxide nanoparticles. Anal. Chem. 2018, 90, 1959-1966. [CrossRef]

58. Rai, P.; Yu, Y.T. Citrate-assisted hydrothermal synthesis of single crystalline ZnO nanoparticles for gas sensor application. Sens. Actuators B Chem. 2012, 173, 58-65. [CrossRef]

59. Srinivasan, P.; Rayappan, J.B.B. Investigations on room temperature dual sensitization of $\mathrm{ZnO}$ nanostructures towards fish quality biomarkers. Sens. Actuators B Chem 2019. In press. [CrossRef]

60. Fu, X.; Liu, J.; Han, T.; Zhang, X.; Meng, F.; Liu, J. A three-dimensional hierarchical CdO nanostructure: Preparation and its improved gas-diffusing performance in gas sensor. Sens. Actuators B Chem. 2013, 184, 260-267. [CrossRef]

61. Rai, P.; Song, H.M.; Kim, Y.S.; Song, M.K.; Oh, P.R.; Yoon, J.M.; Yu, Y.T. Microwave assisted hydrothermal synthesis of single crystalline $\mathrm{ZnO}$ nanorods for gas sensor application. Mater. Lett. 2012, 68, 90-93. [CrossRef]

62. Rai, P.; Raj, S.; Ko, K.J.; Park, K.K.; Yu, Y.T. Synthesis of flower-like ZnO microstructures for gas sensor applications. Sens. Actuators B Chem. 2013, 178, 107-112. [CrossRef]

63. Patil, V.B.; Adhyapak, P.V.; Patil, P.S.; Suryavanshi, S.S.; Mulla, I.S. Hydrothermally synthesized tungsten trioxide nanorods as $\mathrm{NO}_{2}$ gas sensors. Ceram. Int. 2015, 41, 3845-3852. [CrossRef]

64. Zhang, S.L.; Lim, J.O.; Huh, J.S.; Noh, J.S.; Lee, W. Two-step fabrication of ZnO nanosheets for high-performance VOCs gas sensor. Curr. Appl. Phys. 2013, 13, S156-S161. [CrossRef]

65. Mani, G.K.; Rayappan, J.B.B. Novel and facile synthesis of randomly interconnected ZnO nanoplatelets using spray pyrolysis and their room temperature sensing characteristics. Sens. Actuators B Chem. 2014, 198, 125-133. [CrossRef]

66. Subbiah, D.K.; Mani, G.K.; Babu, K.J.; Das, A.; Rayappan, J.B.B. Nanostructured ZnO on cotton fabrics-A novel flexible gas sensor \& UV filter. J. Clean. Prod. 2018, 194, 372-382.

67. Patil, P.; Nakate, U.T.; Nakate, Y.T.; Ambare, R.C. Acetaldehyde sensing properties using ultrafine CuO nanoparticles. Mater. Sci. Semicond. Proc. 2019, 101, 76-81. [CrossRef]

68. Chava, R.K.; Cho, H.Y.; Yoon, J.M.; Yu, Y.T. Fabrication of aggregated $\operatorname{In}_{2} \mathrm{O}_{3}$ nanospheres for highly sensitive acetaldehyde gas sensors. J. Alloy. Comp. 2019, 772, 834-842. [CrossRef]

69. Srinath, A.K.; Sankaranarayanan, L.; Pandeeswari, R.; Jeyaprakash, B.G. Thin films of $\alpha-\mathrm{Mn}_{2} \mathrm{O}_{3}$ for resistance-based sensing of acetaldehyde vapor at ambient temperature. Microchim. Acta 2015, 182, 1619-1626. [CrossRef]

70. Chu, X.; Hu, T.; Gao, F.; Dong, Y.; Sun, W.; Bai, L. Gas sensing properties of graphene-WO $\mathrm{W}_{3}$ composites prepared by hydrothermal method. Mater. Sci. Eng. B 2015, 193, 97-104. [CrossRef]

71. Fu, Q.; Ai, M.; Duan, Y.; Lu, L.; Tian, X.; Sun, D.; Sun, Y. Synthesis of uniform porous NiO nanotetrahedra and their excellent gas-sensing performance toward formaldehyde. RSC Adv. 2017, 7, 52312-52320. [CrossRef]

72. Wang, Z.; Hou, C.; De, Q.; Gu, F.; Han, D. One-step synthesis of Co-doped $\mathrm{In}_{2} \mathrm{O}_{3}$ nanorods for high response of formaldehyde sensor at low temperature. ACS Sens. 2018, 3, 468-475. [CrossRef]

73. Saidi, T.; Palmowski, D.; Babicz-Kiewlicz, S.; Welearegay, T.G.; El Bari, N.; Ionescu, R.; Smulko, J.; Bouchikhi, B. Exhaled breath gas sensing using pristine and functionalized $\mathrm{WO}_{3}$ nanowire sensors enhanced by UV-light irradiation. Sens. Actuators B Chem. 2018, 273, 1719-1729. [CrossRef]

74. Espid, E.; Taghipour, F. UV-LED photo-activated chemical gas sensors: A review. Crit. Rev. Solid State Mater. Sci. 2017, 42, 416-432. [CrossRef]

75. De Lacy Costello, B.P.J.; Ewen, R.J.; Ratcliffe, N.M.; Richards, M. The characteristics of novel low-cost sensors for volatile biomarker detection. J. Breath Res. 2008, 2, 037017. [CrossRef] [PubMed]

76. Xu, J.; Han, J.; Zhang, Y.; Sun, Y.A.; Xie, B. Studies on alcohol sensing mechanism of ZnO based gas sensors. Sens. Actuators B Chem. 2008, 132, 334-339. [CrossRef] 
77. Shimizu, Y.; Yamaguchi, K.; Fukunaga, K.; Takao, Y.; Hyodo, T.; Egashira, M. Acetaldehyde gas-sensing properties and surface chemistry of $\mathrm{SnO}_{2}$-based sensor materials. J. Electrochem. Soc. 1999, 146, 1222-1226. [CrossRef]

78. Majhi, S.M.; Lee, H.J.; Choi, H.N.; Cho, H.Y.; Kim, J.S.; Lee, C.R.; Yu, Y.T. Construction of novel hybrid $\mathrm{PdO}-\mathrm{ZnO}$ p-n heterojunction nanostructures as a high-response sensor for acetaldehyde gas. CrystEngComm 2019, 21, 5084-5094. [CrossRef]

79. Allen, M.J.; Tung, V.C.; Kaner, R.B. Honeycomb carbon: A review of graphene. Chem. Rev. 2009, 110, $132-145$. [CrossRef]

80. Deng, S.; Liu, X.; Chen, N.; Deng, D.; Xiao, X.; Wang, Y. A highly sensitive VOC gas sensor using p-type mesoporous $\mathrm{Co}_{3} \mathrm{O}_{4}$ nanosheets prepared by a facile chemical coprecipitation method. Sens. Actuators $B$ Chem. 2016, 233, 615-623. [CrossRef]

81. Cho, S.Y.; Yoo, H.W.; Kim, J.Y.; Jung, W.B.; Jin, M.L.; Kim, J.S.; Jung, H.T. High-resolution p-type metal oxide semiconductor nanowire array as an ultrasensitive sensor for volatile organic compounds. Nano Lett. 2016, 16, 4508-4515. [CrossRef]

82. Wang, L.; Deng, J.; Lou, Z.; Zhang, T. Nanoparticles-assembled $\mathrm{Co}_{3} \mathrm{O}_{4}$ nanorods p-type nanomaterials: One-pot synthesis and toluene-sensing properties. Sens. Actuators B Chem. 2014, 201, 1-6. [CrossRef]

83. Gunasekaran, E.; Ezhilan, M.; Mani, G.K.; Shankar, P.; Kulandaisamy, A.J.; Rayappan, J.B.B.; Babu, K.J. Fluorine doped $\mathrm{ZnO}$ thin film as acetaldehyde sensor. Semicond. Sci. Technol. 2018, 33, 095005. [CrossRef]

(C) 2019 by the authors. Licensee MDPI, Basel, Switzerland. This article is an open access article distributed under the terms and conditions of the Creative Commons Attribution (CC BY) license (http://creativecommons.org/licenses/by/4.0/). 